\title{
Assessing Chemistry Laboratory Skills Through a Competency-based Approach in High School Chemistry Course
}

\author{
Lucila Giammatteo $^{1,2 *}$, Adolfo V. Obaya ${ }^{1}$ \\ ${ }^{1}$ Chemistry Department, Facultad de Estudios Superiores Cuautitlán, Univerisdad Nacional Autónoma de México, ${ }^{2}$ Instituto Superior de Estudios \\ Superiores de Monterrey, Campus Estado de México
}

*Corresponding Author: giammatteo@itesm.mx

\section{ABSTRACT}

The present paper offers a competency-based approach to evaluate high school laboratory skills during a chemistry course. The Secretaría de Educación Pública (Mexico's Ministry of Education) has identified experimental sciences specific competencies that are to be established in high school. This study investigated the following competencies: Formulating scientific questions, posing hypothesis, obtaining and registering information, applying safety norms in handling substances, materials and equipment, conducting practical activities appropriately in the laboratory, handling residues, collecting qualitative and quantitative data, contrasting results, communicating conclusions, and documenting information sources. An assessment tool where the students' level of achievements was created. This assessment tool evaluated these competencies by considering the curriculum and the students' graduate profile. Results indicated that by having a consistent evaluation plan and providing students with effective feedback, the students competency levels addressed in laboratory practical's can be improved significantly.

KEY WORDS: competency-based assessment; experimental competencies; laboratory assessment; chemistry assessment

\section{INTRODUCTION}

I $\mathrm{n}$ the past 10 years, an educational revolution has shifted the focus of the learning and teaching process to enable students to become more autonomous and self-driven. Particularly, in Mexico, with the implementation of the Reforma Integral de Educación Media Superior (RIEMS) since 2009, most schools have adapted their educational model to a competency-based one. This educational reform establishes a set of outcomes that students should acquire by the end of high school, expressed in terms of general and specific competencies. The experimental sciences competencies are focused on students knowing and applying scientific methods and procedures to solve problems in familiar settings and understanding their environment in a rational way (Secretaría de Educación Pública, 2008).

Despite all efforts made, there is still an enormous gap between the competencies that students should acquire and the way they are being evaluated (Obaya, Vargas, and Delgadillo, 2011).. The evaluation focus in a competency-based approach should not only reflect the learner's knowledge but also abilities, for him/her to progress in an effective way (Monzo, 2009). It is of extreme importance to set aside the measurement of products since a competency-based approach implies focusing on the process (Gonczi, 1994; Velde, 1999; Moreno, 2012). Therefore, a change in evaluation philosophy is required where the teacher should look for evaluating alternatives that transform the student into a protagonist in the learning process (Westera, 2001; Obaya and Ponce, 2010).

There are many issues concerning current evaluation that do not match the competency-based model (Voorhees, 2001).
First, current evaluations favor mechanical processes since most content and procedures have already been established. Moreover, there is a gap between theoretical knowledge and practical skills. Since most methods are standardized, students' individuality is lost in the process. Last but not least, traditional evaluation emphasizes quantitative grades leading students to focus on numbers, rather than focusing on acquired knowledge or skills (Falander and Shafranske, 2007; Echeverry, Arenas, and Bohorquez, 2015; Muñoz, Medina and Guillén, 2015).

Based on the points described above, we argue the following characteristics are essential in a competency-based approach:

- The assessment should take place during the whole process

- Genuine feedback for both students and teachers is essential

- Evaluation is focused on the process rather than on the result

- The main interest is for the learner to have an active role in the learning process

- The process is multidirectional and collaborative

- The assessment allows to establish the competencies level of achievement.

An appropriate assessment should be related to the objectives of teaching, and skills assessment should indicate how effective learning strategies are. A good assessment is defined as reliable, valid, and practicable and that it should have educational value (Shafi et al., 2010; Couch et al., 2015).

The following work proposes a novel competency-based strategy to evaluate students' performance in the laboratory, 
taking into account the specific competencies related to experimental sciences in a high school chemistry course. By proposing specific criteria, teachers and students can understand the learning process better. This, in turn, should lead to more autonomy and self-regulation (Gavilan et al., 2013). If specific evaluation instruments that are reliable and representatives are designed, students' acquisition of competencies can be verified (Arellano and Lazo, 1999; Thompson et al., 2013).

\section{METHODOLOGY}

Given the RIEMS document (2008) where the competencies were established, the following specific competencies were selected to be evaluated throughout a semester:

- Students identify problems, formulate scientific questions, and pose the necessary hypotheses to solve them.

- Students obtain, register, and systematize information to respond to scientific questions, consulting relevant sources, and carrying out experiments.

- Students contrast obtained results in an investigation or experiment with previous hypotheses and communicate conclusions.

- Students apply security norms in handling substances, instruments, and equipment in daily life activities.

An assessment tool [Table 1] describes the levels of achievement of each competency, which was developed according to the course curriculum and the graduate profile of the third-semester high school students taking the subject "Matter and the Environment" at Instituto Tecnológico de Monterrey, Campus Estado de México.

A sample of 24 students, 12 females and 12 males with an average age of 16 years old, were randomly chosen based on course enrolment. Students divided themselves into teams of four or five for conducting the laboratory practicals. The teams remained unchanged for a 6-month period, which corresponded to the duration of the chemistry course.

Seven laboratory practicals were performed during the course, concerning the topics established in the curriculum. The contents of the laboratory practicals were the following:

1. Physical and chemical changes

2. Mixture separation methods

3. Water properties

4. Oxyacids and hydroxides

5. Chemical reactions and stoichiometry

6. Gas laws

7. $\mathrm{pH}$ in everyday life

The students' specific competencies were evaluated individually and as a team with the following instruments: Individual previous questionnaire, individual laboratory work, and a laboratory report per team (Rogers, 2001). The individual previous questionnaire consisted of three-six theoretical questions that introduced the student to the topic. This questionnaire was submitted individually. Each student was required to write a hypothesis for each practical, based on the learning objective provided by the teacher. Students submitted their hypothesis through an educational platform (Blackboard) 1 day before the practical took place. The intention of the questionnaire was to familiarize the students with the topics, as well as assessing their ability to formulate hypothesis and to obtain, register, and systematize information (a sample of these questionnaires is included as Annex 1). Individual laboratory work was assessed by the teacher during the laboratory session. The laboratory report was written in teams and submitted through Blackboard. These reports were required to be submitted within 3 days after the experimental session took place. For each practical, the students were evaluated using the assessment tool included in Table 1. Prompt feedback was given to students within a week of having performed the practical. The comments were delivered electronically through Blackboard. As noted by several authors, feedback is essential in competency-based models since it enables students to improve their performance gradually by correcting attitudes, behaviors, and skills (Frade, 2009; Monzo, 2009; Obaya and Ponce, 2010).

\section{RESULTS}

Table 2 summarizes the results for each laboratory report. As stated in the educational reform, contrasting results and communicating conclusions are considered as one competency. However, we subdivided it because it implies two different processes. Contrasting results require students to compare the result of the experiment with theoretical information, whereas communicating conclusion condenses the previous information and helps the students accept or refute their hypothesis. While the discussion requires analysis on behalf of the student, concluding involves judgment and synthesis.

Graph 1 compares the levels of achievement from each competency in the first and the last laboratory report. When comparing them, an improvement in terms of competencies achievement is shown.

\section{DISCUSSION}

It is evident from Graph 1 that at the beginning of the semester, most students were not able to formulate hypotheses. Even

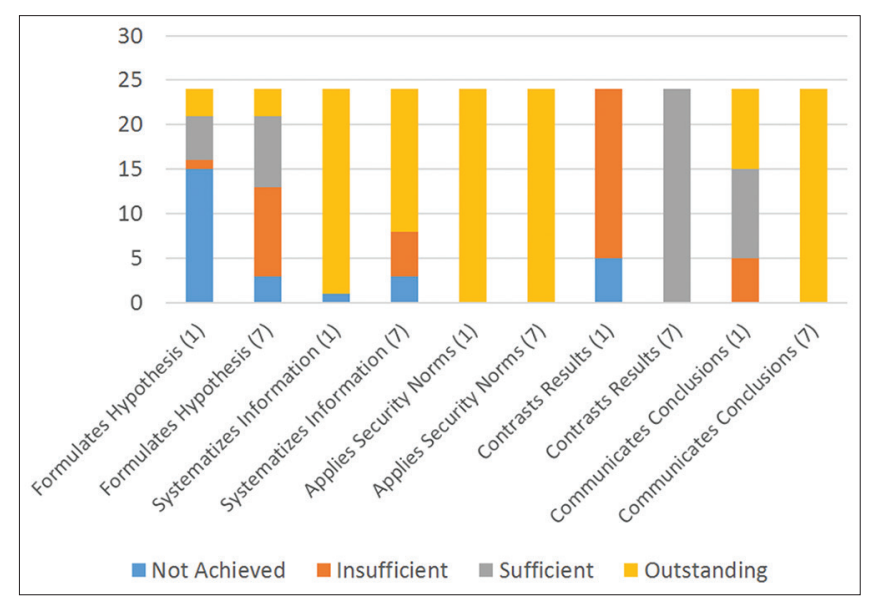

Graph 1: Comparison between achieved competencies in reports 1 and 7 
Table 1: Assessment tool for experimental disciplinary competences

\begin{tabular}{|c|c|c|c|c|c|c|}
\hline \multirow[t]{2}{*}{ Competency } & \multirow{2}{*}{$\begin{array}{l}\text { Performance } \\
\text { indicators }\end{array}$} & \multicolumn{4}{|l|}{ Achievement level } & \multirow[t]{2}{*}{ Points } \\
\hline & & Not achieved & Insufficient & Sufficient & Outstanding & \\
\hline \multirow[t]{2}{*}{$\begin{array}{l}\text { Previous } \\
\text { questionnaire }\end{array}$} & $\begin{array}{l}\text { Formulates a } \\
\text { scientific question } \\
\text { and poses the } \\
\text { hypothesis } \\
\text { needed to answer } \\
\text { it }\end{array}$ & $\begin{array}{l}\text { The previous } \\
\text { questionnaire lacks } \\
\text { questions and } \\
\text { implicit or explicit } \\
\text { hypotheses. (0) }\end{array}$ & $\begin{array}{l}\text { In the previous } \\
\text { questionnaire, the student } \\
\text { poses at least one scientific } \\
\text { question. Hypothesis is not } \\
\text { included. (5) }\end{array}$ & $\begin{array}{l}\text { In the previous } \\
\text { questionnaire, besides } \\
\text { formulating a scientific } \\
\text { question, a hypothesis } \\
\text { is included which is not } \\
\text { written in the correct way or } \\
\text { cannot be tested. ( } 7 \text { ) }\end{array}$ & $\begin{array}{l}\text { Besides formulating the } \\
\text { scientific question, a } \\
\text { hypothesis is included } \\
\text { which is written in an } \\
\text { appropriate way and } \\
\text { can be tested (includes } \\
\text { variables, it is precise, } \\
\text { it is written in an } \\
\text { affirmative way). (10) }\end{array}$ & $/ 10$ \\
\hline & $\begin{array}{l}\text { Obtains, registers, } \\
\text { and systematizes } \\
\text { information to } \\
\text { respond scientific } \\
\text { questions }\end{array}$ & $\begin{array}{l}\text { The student does } \\
\text { not answer the } \\
\text { questions included } \\
\text { in the previous } \\
\text { questionnaire. (0) }\end{array}$ & $\begin{array}{l}\text { Most of the questions } \\
\text { included in the previous } \\
\text { questionnaire are answered } \\
\text { incorrectly and/or in an } \\
\text { incomplete way. (5) }\end{array}$ & $\begin{array}{l}\text { Most of the questions } \\
\text { included in the previous } \\
\text { questionnaire are answered } \\
\text { correctly and in a complete } \\
\text { way. ( } 7 \text { ) }\end{array}$ & $\begin{array}{l}\text { All of the questions } \\
\text { included in the previous } \\
\text { questionnaire are } \\
\text { answered correctly and } \\
\text { in a complete way. (10) }\end{array}$ & $/ 10$ \\
\hline \multirow[t]{3}{*}{ Laboratory work } & $\begin{array}{l}\text { Applies safety } \\
\text { norms in handling } \\
\text { substances, } \\
\text { instruments, and } \\
\text { equipment }\end{array}$ & $\begin{array}{l}\text { Basic safety rules } \\
\text { are not followed, } \\
\text { including the use of } \\
\text { gloves, laboratory } \\
\text { coat, mask, and } \\
\text { safety glasses. (0) }\end{array}$ & & & $\begin{array}{l}\text { All team members use } \\
\text { safety gear (gloves, } \\
\text { mask, safety glasses, and } \\
\text { laboratory coat) during } \\
\text { the whole laboratory } \\
\text { practice. ( } 5 \text { ) }\end{array}$ & 15 \\
\hline & $\begin{array}{l}\text { Conduct and } \\
\text { discipline in the } \\
\text { laboratory }\end{array}$ & $\begin{array}{l}\text { The student does } \\
\text { not respect the } \\
\text { laboratory rules and } \\
\text { does not behave } \\
\text { appropriately. }(0)\end{array}$ & & & $\begin{array}{l}\text { The student respects } \\
\text { rules, follows } \\
\text { instructions, and behaves } \\
\text { according to a laboratory } \\
\text { context. (10) }\end{array}$ & $/ 10$ \\
\hline & $\begin{array}{l}\text { Handles residues } \\
\text { in an appropriate } \\
\text { way }\end{array}$ & $\begin{array}{l}\text { Instructions to } \\
\text { dispose residues } \\
\text { are not followed } \\
\text { correctly and } \\
\text { securely. }(0)\end{array}$ & & & $\begin{array}{l}\text { The residues are } \\
\text { disposed of according to } \\
\text { instructions in the given } \\
\text { containers. (5) }\end{array}$ & $/ 5$ \\
\hline \multirow[t]{3}{*}{ Report } & $\begin{array}{l}\text { Collects } \\
\text { qualitative and } \\
\text { quantitative data }\end{array}$ & $\begin{array}{l}\text { Data collection is } \\
\text { not included. }(0)\end{array}$ & $\begin{array}{l}\text { Presented data are not } \\
\text { enough to sustain the } \\
\text { conclusions. (10) }\end{array}$ & $\begin{array}{l}\text { Quantitative and qualitative } \\
\text { data are included, though } \\
\text { they are presented in a } \\
\text { disorganized way. (15) }\end{array}$ & $\begin{array}{l}\text { Collected data are } \\
\text { enough to reach a } \\
\text { conclusion and it } \\
\text { is presented in an } \\
\text { organized way. (20) }\end{array}$ & $/ 20$ \\
\hline & $\begin{array}{l}\text { Contrasts } \\
\text { obtained } \\
\text { results in an } \\
\text { investigation or } \\
\text { experiment }\end{array}$ & $\begin{array}{l}\text { Obtained results } \\
\text { are not justified. } \\
\text { Experimental errors } \\
\text { are not described. }(0)\end{array}$ & $\begin{array}{l}\text { The student attempts to } \\
\text { explain results, even though } \\
\text { they are not justified with } \\
\text { theoretical background. } \\
\text { Experimental errors are not } \\
\text { described. (10) }\end{array}$ & $\begin{array}{l}\text { Obtained data are justified } \\
\text { with theoretical background. } \\
\text { Experimental errors are not } \\
\text { described. (15) }\end{array}$ & $\begin{array}{l}\text { Experimental data } \\
\text { are justified with } \\
\text { theoretical background. } \\
\text { If data do not match, an } \\
\text { explanation is provided. } \\
\text { A brief description of } \\
\text { experimental errors is } \\
\text { also provided. (20) }\end{array}$ & $/ 20$ \\
\hline & $\begin{array}{l}\text { Communicate } \\
\text { conclusions }\end{array}$ & $\begin{array}{l}\text { Conclusions are not } \\
\text { registered. (0) }\end{array}$ & $\begin{array}{l}\text { The student develops a } \\
\text { conclusion that is not fully } \\
\text { related to the objective and } \\
\text { the hypothesis. (5) }\end{array}$ & $\begin{array}{l}\text { The student develops a } \\
\text { conclusion that it is not fully } \\
\text { related to the objective or } \\
\text { the hypothesis. ( } 7 \text { ) }\end{array}$ & $\begin{array}{l}\text { The student concludes } \\
\text { based on the obtained } \\
\text { results, in congruence } \\
\text { with the laboratory } \\
\text { practice objective and } \\
\text { the hypothesis. (10) }\end{array}$ & $/ 10$ \\
\hline $\begin{array}{l}\text { Information } \\
\text { sources }\end{array}$ & $\begin{array}{l}\text { Documents } \\
\text { information } \\
\text { sources in APA }\end{array}$ & $\begin{array}{l}\text { The student does } \\
\text { not include sources } \\
\text { of information } \\
\text { in the previous } \\
\text { questionnaire and } \\
\text { the report. (0) }\end{array}$ & $\begin{array}{l}\text { The student reports } \\
\text { information sources } \\
\text { without respecting APA } \\
\text { format. (5) }\end{array}$ & $\begin{array}{l}\text { The student obtains } \\
\text { information from } \\
\text { unreliable sources reported } \\
\text { in APA format, or the } \\
\text { information used does not } \\
\text { match with the reported } \\
\text { sources. ( } 7)\end{array}$ & $\begin{array}{l}\text { All the sources of } \\
\text { information are } \\
\text { reliable, are used } \\
\text { appropriately, and } \\
\text { are reported in APA } \\
\text { format. (10) }\end{array}$ & \\
\hline
\end{tabular}

of how to write a hypothesis and the differences between dependent and independent variables. By the seventh report, approximately half of the students were still struggling with the hypotheses, though at least an attempt to write one was 
made. Student's improvements are shown in Graph 1, where the transition between not achieved and insufficient is visible. The increase of students in the sufficient level is notable, whereas the outstanding level remained unchanged. Those students who had already mastered writing hypothesis before the beginning of the course remained the same while more students were assessed as sufficient none from Laboratory 1 moved from sufficient to outstanding.

In most cases, the competency for systematizing information was outstanding. This was related to the educational strategies used in the entire chemistry course, which were inquiry based. Hence, it has an impact when answering the questions posed in the previous questionnaire. The notable difference between reports 1 and 7 has to do with increasing complexity of the questions included [Table 2].

Reporting references in APA (2010) style were assessed in both the previous questionnaire and laboratory report because it is implicit that to obtain and register information for answering scientific questions, one has to be able to give credit to the authors. In regard of the references, the ability to find reliable sources was also assessed by checking the articles, books, and web pages that students selected to answer the questions and argue their results.

Safety norms in the chemistry laboratory are well-established from the beginning of the semester. There is a set of rules and regulations that students must follow during laboratory practicals, including the use of safety gear (laboratory coat, gloves, and safety goggles). Students were not allowed to enter the laboratory if they did not comply with security regulations. Therefore, the obtained results for this competency remaining unchanged during the semester was not unexpected.

When assessing the competency for contrasting obtained results, it can be seen that at the beginning these students were not able to explain the results of their experiments by justifying them

\begin{tabular}{|c|c|c|c|c|c|c|}
\hline $\begin{array}{l}\text { Laboratory } \\
\text { Reports }\end{array}$ & Level of achievement & $\begin{array}{l}\text { Formulates } \\
\text { hypothesis }\end{array}$ & $\begin{array}{c}\text { Systematizes } \\
\text { information }\end{array}$ & $\begin{array}{c}\text { Applies security } \\
\text { norms }\end{array}$ & $\begin{array}{l}\text { Contrast } \\
\text { results }\end{array}$ & $\begin{array}{c}\text { Communicate } \\
\text { conclusions }\end{array}$ \\
\hline \multirow{4}{*}{$\begin{array}{l}\text { Laboratory } \\
\text { report } 1\end{array}$} & Not achieved & 15 & 1 & 0 & 5 & 0 \\
\hline & Insufficient & 1 & 0 & 0 & 19 & 5 \\
\hline & Sufficient & 5 & 0 & 0 & 0 & 10 \\
\hline & Outstanding & 3 & 23 & 24 & 0 & 9 \\
\hline \multirow{4}{*}{$\begin{array}{l}\text { Laboratory } \\
\text { report } 2\end{array}$} & Not achieved & 15 & 0 & 0 & 5 & 0 \\
\hline & Insufficient & 3 & 0 & 0 & 5 & 10 \\
\hline & Sufficient & 2 & 2 & 0 & 14 & 0 \\
\hline & Outstanding & 4 & 22 & 24 & 0 & 14 \\
\hline \multirow{4}{*}{$\begin{array}{l}\text { Laboratory } \\
\text { report } 3\end{array}$} & Not achieved & 7 & 3 & 0 & 9 & 0 \\
\hline & Insufficient & 12 & 3 & 0 & 10 & 0 \\
\hline & Sufficient & 5 & 1 & 0 & 5 & 10 \\
\hline & Outstanding & 0 & 17 & 24 & 0 & 14 \\
\hline \multirow{4}{*}{$\begin{array}{l}\text { Laboratory } \\
\text { report } 4\end{array}$} & Not achieved & 13 & 1 & 0 & 0 & 0 \\
\hline & Insufficient & 6 & 9 & 0 & 19 & 5 \\
\hline & Sufficient & 1 & 5 & 0 & 0 & 0 \\
\hline & Outstanding & 4 & 9 & 24 & 5 & 19 \\
\hline \multirow{4}{*}{$\begin{array}{l}\text { Laboratory } \\
\text { report } 5\end{array}$} & Not achieved & 7 & 0 & 0 & 0 & 0 \\
\hline & Insufficient & 1 & 1 & 0 & 24 & 5 \\
\hline & Sufficient & 4 & 6 & 0 & 0 & 0 \\
\hline & Outstanding & 12 & 17 & 24 & 0 & 19 \\
\hline \multirow{4}{*}{$\begin{array}{l}\text { Laboratory } \\
\text { report } 6\end{array}$} & Not achieved & 6 & 1 & 0 & 5 & 0 \\
\hline & Insufficient & 2 & 0 & 0 & 14 & 0 \\
\hline & Sufficient & 9 & 5 & 0 & 5 & 14 \\
\hline & Outstanding & 7 & 18 & 24 & 0 & 10 \\
\hline \multirow{4}{*}{$\begin{array}{l}\text { Laboratory } \\
\text { report } 7\end{array}$} & Not achieved & 3 & 3 & 0 & 0 & 0 \\
\hline & Insufficient & 10 & 5 & 0 & 0 & 0 \\
\hline & Sufficient & 8 & 0 & 0 & 24 & 0 \\
\hline & Outstanding & 3 & 16 & 24 & 0 & 24 \\
\hline
\end{tabular}


with a theoretical background. One suggestion for improvement would be for the teacher to enhance the link between theory and practice because most laboratory practicals were also revised in class from a theoretical perspective. Providing feedback is essential at this stage to support students through the process. Compared to the rest of the class, most of the students that achieved a sufficient level in this competency were more autonomous during the course and tracked their progress in a more direct way. As an example, in addition to the comments, they got through Blackboard; these students would approach the teacher for more specific comments on their performance and way to improve their work for the upcoming report.

By the end of the semester, all of the students were able to communicate conclusions effectively. At this point, students were capable to relate their objective and hypothesis to the obtained results to come up with a conclusion.

Variations in the obtained results during the process may be due to several factors. One of them was that students work distribution for the laboratory report was not always the same. For a more accurate assessment of the competencies mentioned, it is recommended to evaluate the reports individually. Another important factor to have in mind is that since the topics distribution varies along the semester, the order of laboratory practicals does not necessarily go of increasing difficulty. This means that some of the most complex laboratory procedures took place in the beginning of the semester, influencing especially the contrasting obtained results competency as noted in Table 2 .

Since the competencies were to be established over an entire school year, it is necessary to take into consideration that these results correspond to only half of that period. Therefore, the same evaluation scheme is proposed as a plan for the second half of the year in which students take another chemistry course to ensure that the competencies are achieved in compliance to the graduate profile.

\section{CONCLUSIONS}

An evaluation plan that considers not only raw knowledge but also abilities, skills, and attitudes is definitely necessary if a competency-based model is applied. This plan has to include different moments in the evaluation process and a series of instruments based on the students' intended level of achievement.

The main purpose of evaluation should be to provide the learners with authentic feedback that would eventually lead to autonomy and self-regulation so that they become active participants of the learning process.
Teachers should minimize the breach between the competencies worked in class and the evaluation of such competencies and ensures a reliable and representative process that provides useful information that enriches the learning process.

\section{REFERENCES}

American Psychological Association (APA). (2010). Publication Manual of the American Psychological Association. $6^{\text {th }}$ ed. Washington, DC: American Psychological Association.

Arellano, M., \& Lazo, S. (1999). Evaluación del logro de las competencias básicas en el laboratorio de Química general. Educación Química, 10(1), 49-53.

Couch, B., Brown, T., Schelpat, T, Graham, M., \& Knight, J. (2015). Scientific teaching: Defining a taxonomy of observable practices. $C B E$ Life Sciences Education, 14, 1-12.

Echeverry, E., Arenas, W., \& Bohorquez, N. (2015). Implementación de laboratorios lúdicos para la evaluación por competencias desde un enfoque constructivista. Educación en Ingeniería, 10(20), 123-132.

Falender, C., \& Shafranske, E. (2007). Competence in competencybased supervision practice: Construct and application. Professional Psychology: Research and Practice, 38(3), 232-240.

Frade, L. (2009). Desarrollo de Competencias en Educación Básica. Ciudad de México, México: Calidad Educativa Consultores.

Gavilan, I., Cano, S., \& Aburto, S. (2013). Diseño de herramientas didácticas basado en competencias para la enseñanza de química ambiental. Educación Química, 24(3), 298-308.

Gonczi, A. (1994). Competency based assessment in professions in Australia. Assessment in Education, 1, 27-44.

Monzo, R. (2009). Evaluación basada en competencias. Revista Panamericana de Pedagogía, 6, 131-144.

Moreno, T. (2012). La evaluación de competencias en la educación. Sinéctica, 39, 1-22.

Muñoz, F., Medina, A., \& Guillen, M. (2015). Jerarquización de competencias genéricas basadas en las percepciones de docentes universitarios. Educación Química, 27, 126-132.

Obaya, A., \& Ponce, R. (2010). Evaluación del aprendizaje basado en el desarrollo de competencias. Contactos, 76, 31-37.

Obaya, A., Vargas, Y.M., \& Delgadillo, G. (2011). Aspectos relevantes de la educación basada en competencias para la formación profesional. Educación Química, 22(1), 63-68.

Rogers, I. (2001). Integrated Learning Systems- an open approach. International Journal of Science Education, 23(4), 405-422.

Secretaria deEducacion Publica(SEP).(2008). Reforma IntegraldeEducación Media Superior (RIEMS). Acuerdo 444. Available from: http://www. dof.gob.mx/nota detalle.php? codigo $=5061936 \&$ fecha $=26 / 09 / 2008$. [Last acessed on 2017 Dec 15].

Shafi, R., Irshad, K., \& Iqbal, M. (2010). Competency-based integrated practical examinations: Bringing relevance to basic science laboratory examinations. Medical Teacher, 32, 443-447.

Thompson, K., Chmielewski, J., Gaines, M., Hrycyna, C., \& Lacourse, W. (2013). Competency-based reforms of undergraduate biology sciences. CBE-Life Sciences Education, 12, 162-169.

Velde, C. (1999). An alternative conception of competence: Implications for vocational education. Journal of Vocational Education and Training, 51(3), 437-447.

Voorhees, A.B. (2001). Creating and implementing competency-based learning models. Special Issue: Measuring What Matters: CompetencyBased Learning Models in Higher Education, 110, 83-95.

Westera, W. (2001). Competences in education: A confusión of tongues. Journal of Curriculum Studies, 33(1), 75-88. 
Annex 1: Previous questionnaire and laboratory report format

Matter and the environment - Laboratory report

General Data

Group

Professor

Practice No. 1 Practice name Physical and chemical changes

Team members

Instructions

1. Before the laboratory practice, you have to read carefully the introduction and the methodology. You will answer the previous questionnaire and propose a hypothesis individually. This will be delivered according to instructions $24 \mathrm{~h}$ before the practice

2. The report will be delivered in the corresponding due date, after the practice has been done. This is made in teams. Only one report will be delivered according to your teacher's instructions

3. You can consult the procedure for the laboratory practice in your device

\section{Previous questionnaire (individual)}

Define chemical change, including at least two characteristics

Define physical change, including at least two characteristics

What properties are chemical changes based on?

What properties are physical changes based on?

Mention five examples of physical and chemical changes

\section{Introduction}

Phenomena that occur in nature are due to changes in matter which are classified as physical or chemical. In a physical change, the chemical structure of matter remains unaltered. Examples of physical properties are melting, evaporation, elasticity, etc., On the contrary, a chemical change supposes an alteration in the internal structure of matter. Examples of chemical properties are: Combustion, oxidation, and precipitation

It is necessary for a change to present to know what type of property is manifested; the series of change provide important information to identify properties, characteristics, and applications of the different substances

\section{Objective}

\section{Hypothesis}

\begin{tabular}{ll}
\hline Materials and Reagents \\
\hline Per team & $\cdot$ Eggshell \\
& $\cdot$ Sugar $(5 \mathrm{~g})$ \\
& $\cdot$ Milk $(10 \mathrm{~mL})$ \\
& $\cdot$ Lemon $(1 \mathrm{cut}$ in half $)$ \\
& $\cdot$ Powder \\
Teacher & $\cdot$ Concentrated HNO3 (substance B) \\
& $\cdot 10 \mathrm{~mL}$ pipette \\
& $\cdot$ mL Erlenmeyer flask \\
& $\cdot 10 \mathrm{~mL}$ beaker \\
& $\cdot 50 \mathrm{~mL}$ beaker \\
& $\cdot 1$ wash bottle with distilled water \\
& $\cdot 1$ melting spoon \\
& $\cdot 1$ glass rod \\
& $\cdot 1$ porcelain capsule \\
& $\cdot$ glass watch \\
& $\cdot$ Ketone \\
& $\cdot$ Concentrated HCl \\
& $\cdot$ Dry ice \\
& $\cdot$ Ether \\
& $\cdot 1$ mortar \\
& $\cdot 1$ Bunsen burner \\
& $\cdot 1$ tube clamp \\
& $\cdot 1$ test tube $(13 \times 100 \mathrm{~mm})$ \\
&
\end{tabular}


Annex 1: (Continued...)

Matter and the environment - Laboratory report

\section{Procedure}

Experiment No. 1

Place 10 drops of ether in a glass watch. Let, it rest and watch it every 10-15 min.

Caution: Keep it away from fire.

Experiment No. 2 (Teacher)

Observe the experiment.

Experiment No. 3

Place a piece of dry ice (solid CO2) in a $50 \mathrm{~mL}$ beaker - do not touch it with your bare hands. In a test tube (13×100 mm), place $1 \mathrm{~mL}$ of water and then add 4-7 $\mathrm{mL}$ of ketone.

Experiment No. 4

Pour $5 \mathrm{~mL}$ of milk in a $10 \mathrm{~mL}$ beaker. Add $1 \mathrm{~mL}$ of concentrated HCL (carefully) or lemon.

Experiment No. 5

Grind sugar with the mortar. Taste it.

Experiment No. 6

Take some sugar, place it in the melting spoon and take it close to the Bunsen burner.

Experiment No. 7

Take a piece of eggshell and place it in a porcelain capsule. Add $1 \mathrm{~mL}$ of concentrated HCL. Wait for 10 min and check it again.

\section{Results}

Experiment

Observations, shape? How did the properties vary? How did time affect your results?)

Type of change (physical or chemical)

1
2
3
4
5
6
7

2

Results analysis and Experimental Errors

Conclusions

Information Sources 